\title{
Evaluating China's Oil Security and Overseas Oil Investment
}

\author{
Yuhua Zheng \\ School of Business Administration, China University of Petroleum-Beijing, Beijing, China \\ Email: cupbazyh@163.com
}

How to cite this paper: Zheng, Y.H. (2017) Evaluating China's Oil Security and Overseas Oil Investment. American Journal of Industrial and Business Management, 7, 959-972.

https://doi.org/10.4236/ajibm.2017.78069

Received: July 24, 2017

Accepted: August 14, 2017

Published: August 17, 2017

Copyright $\odot 2017$ by author and Scientific Research Publishing Inc. This work is licensed under the Creative Commons Attribution International License (CC BY 4.0).

http://creativecommons.org/licenses/by/4.0/

\section{(c) (i) Open Access}

\begin{abstract}
Oil security is the major concern of China's energy policy due to the no effective substitute nature of oil and the heavy reliance on internationally imported crude oil. In this paper, a synthesized indicator system was established to analyze China's oil security from four aspects and Chinese government's oil security policies were also discussed. From this analysis, we concluded that the main risk in China's oil security was the gaps between domestic oil supply and demand, and the main means that Chinese government employed on securing oil safety was oil importing diversification, improving transnational pipeline conditions, and enhancing stable domestic oil production. Furthermore, the multiple roles of overseas equity oil production from Chinese National Oil Companies in securing oil safety were discussed and the possible measures and policies on further improving oil safety were also suggested.
\end{abstract}

\section{Keywords}

Oil Security, Oil Demand and Supply, Overseas Oil Investment

\section{Introduction}

Oil is a strategic resource in international trading and the volatile oil price affects trading price of many other commodities. Oil security is of great concern to most of the world's energy importing countries. Since 1993, China has been a net crude oil importer, and both the absolute amount of crude oil imports and the share of imported oil in total crude oil consumption have risen dramatically. Oil security has become the core of China's energy security and even in economic security, given oil is the only energy for which China relies heavily on international market and is so far irreplaceable in the fast growing transportation sector. 
China's economic growth and industrial restructuring have promoted the rapid growth in oil consumption and the gap between domestic oil demand and supply is widening. Causal relationship existed between China's economic growth and oil consumption (Zou and Chau, 2006 [1]) and the correlation between oil consumption and development of tertiary industries was very high (Zheng and Luo, 2013 [2]). From 2000 to 2015, China's oil production increased from $162 \mathrm{Mt}$ to $210 \mathrm{Mt}$, with an average annual growth rate of $1.90 \%$; while, in the same period, China's oil consumption increased from $224 \mathrm{Mt}$ to $508 \mathrm{Mt}$, with an average annual growth rate of $6.3 \%$. The oil consumption growth rate of tertiary industry is the highest one, and its share in total oil consumption has grown from $22 \%$ in 1990 to $45 \%$ in 2014. With huge improvement in transportation infrastructures and increasing passage and freight turnovers, as an important fuel and chemical raw material, crude oil demand is expected to experience further growth. As the domestic major oil fields are in the later stage of development, with limited production growth potential, how to leverage the gap between demand and supply is a dominant problem for China.

Importing oil from world market and investing in overseas oil and gas assets were recognized as two principal ways that Chinese oil companies employed to acquire overseas oil resources. In 2015, the domestic crude oil production was $210 \mathrm{Mt}$ and the net crude oil imports reached $305 \mathrm{Mt}$, indicating a nearly $60 \%$ oil import dependence. Therefore, the diversification and transportation safety on imported oil are of great importance for China regarding its oil security policies. On the other hand, since China National Petroleum Company's (CNPC's) successful bidding for oil plays of Bangya in 1993, Chinese National Oil Companies (NOCs) have actively participated in the international oil market for mergers and acquisitions (M\&As). The overseas equity oil production (OEOP) exceeded $90 \mathrm{Mt}$. Although only a limited part of the OEOP was shipped back to China due to NOCs' profit concerns and refineries' oil input requirements, both Chinese government and NOCs looked on the investment in the overseas assets as a strategy to secure oil security, and granted many financial and political supports.

The main problems the paper is going to solve are: 1) to evaluate the oil security situation in China over period from 1990 to 2015; 2) to understand the drivers, roles and challenges of China's overseas oil investment through examining structure and composition of Chinese NOCs' overseas mergers and acquisitions; 3) to analyze China's strategic policies regarding improvements in national oil security, and if these policies have mitigated the so called oil insecurity. This paper is structured as follows: Section 2 establishes an indicator system to analyze the oil security by building an indicator system, which focuses on four aspects of oil security, and examines the previous policies regarding oil security issues. Section 3 analyzes the achievements and trends in M\&As from Chinese NOCs in world oil market, and discusses their roles in Chinese oil security strategies. Finally, Section 4 summarizes previous works and provides suggestions on China's policies regarding improving of oil security. 


\section{Assessment of China's Oil Security}

As oil has the unique feature of liquid fuel and political strategic resource, the debate on oil security has always been research focus of energy security. Costantini et al., (2007) [3], Jun E et al. (2009) [4] focused on the impact assessment of oil prices on oil security. Vivoda (2009 [5], 2010 [6]), Cohen et al. (2011) [7], Wu et al. (2007 [8], 2009 [9]), Zhang et al. (2011) [10] studied the risk of oil imports. Lu et al. (2014) [11] assessed the crude oil supply risk. Gupta (2008) [12], Ediger and Berk (2011) [13] proposed oil security assessment method through the establishment of integrated indicator system. Greene (2010) [14] used metrics model to measure the cost of oil dependence. These researches have contributed substantially to the oil security study. After carefully considering the literatures related to oil security, this paper concludes that oil security should have a wide range of perspectives, including access to abundant oil supplies, oil supply diversity, continuity of reasonable price, environmental friendly usage, oil transportation and storage safety. Therefore, a framework of oil security assessment was constructed with four dimensions, which are availability of the oil resource, stability of oil supply domestically and internationally, the affordability of oil importation, and efficiency of oil usage.

\subsection{The Availability of Oil Resource}

In this context, two indicators of per capita domestic oil production $(Q / P)$ and net oil import dependence $(N I D)$ are used to indicate availability of crude oil, as China is the fourth largest oil producer and the second largest oil importer in the world. Per capita domestic oil production is expressed as a ratio of total oil production to population of a nation, indicating the oil supply capacity for the whole nation.Net oil import dependence is the ratio of net oil imports to total oil consumption, indicating the dependence on the international oil market.

1) Per Capita Domestic Oil Production

As shown in Figure 1, China's $Q / P$ has been on the rise from 0.04 ton per capita in 1970 to 0.15 ton per capita in 2014. In the period from 1970 to 1978, China's $Q / P$ experienced the most rapid growth rate of $14.9 \%$ annually, when China's major oil fields of Daqing and Shengli were in production-increasing phrase. After the late 1970s and early 1980s, with 4 - 5 years of negative oil production growth, the $Q / P$ entered a long period of slowly increasing with an average growth rate of $1.39 \%$ from 1983 to 2014 . China's $Q / P$ ranks the 41 th in the 48 oil producing countries with a relatively stable value of $0.14-0.15$ during the past decade. This indicator is expected to decline this year due to the low oil price, which made domestic marginal resources uneconomical and hindered breakthrough from China's unconventional resources. However, Chinese government has always stressed the role of self-oil production in securing of oil safety, and Chinese NOCs have been encouraged to cultivate the development technologies of remaining oil from old oilfields, hard-to-recover reserves, offshore and unconventional oil reservoirs. 


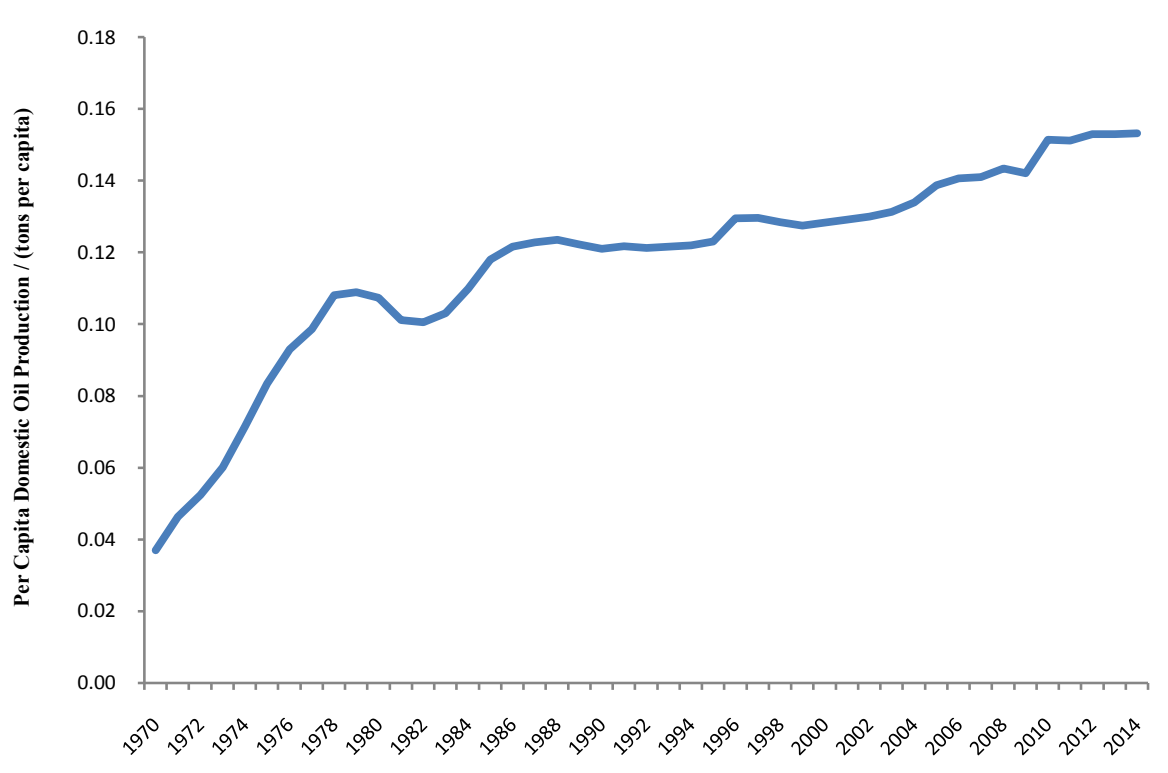

Figure 1. China's per capita domestic oil production. Data source: Chinese statistical yearbook.

\section{2) Net Oil Import Dependence}

NID is the most mentioned indicator in regard to China's oil issue. After the initial success of reform and open up, the rapid economic growth was accompanied by tremendous oil demand and led to the continuous growth of oil import dependency resulting in China's transforming to a net oil importer since 1993. With the opening up of the oil market, oil imported from overseas entered the domestic market more easily than before, making China's dependence on foreign oil increased greatly. China's NID was $30 \%$ in 2002, and then exceeded $50 \%$ in 2007 and reached $60 \%$ in 2014 (see Figure 2). The soaring oil imports in the past 15 years has transformed China from low risk to high risk in oil supply and became the concern of many Chinese diplomatic strategies. In order to ensure sufficient supply of overseas oil imports, Chinese government has paid much efforts toward building long term relationship with resource countries, including providing humanitarian or financial aids, loans-for-resource, even the newly developed The One Belt one Road Initiative $(B \& R)$ which connects China with most of its oil resource countries and oil transportation lanes.

\subsection{The Stability of Oil Supply Domestically and Internationally}

Two indicators of preserve to production ratio $(R / P)$ and risk adjusted diversity index of oil import $(R D I)$ are used to evaluate the stability dimension.

1) Reserve to Production Ratio

The economic implication of reserve to production ratio refers to the time period when the remaining oil reserves can satisfy the exploration and development under the current scale of production. Therefore, it indicates the development potential of oil industry and sustainability of oil supply for a country. The world's oil $R / P$ has been seen an upward trend, rising from 37 in the mid-1980s 


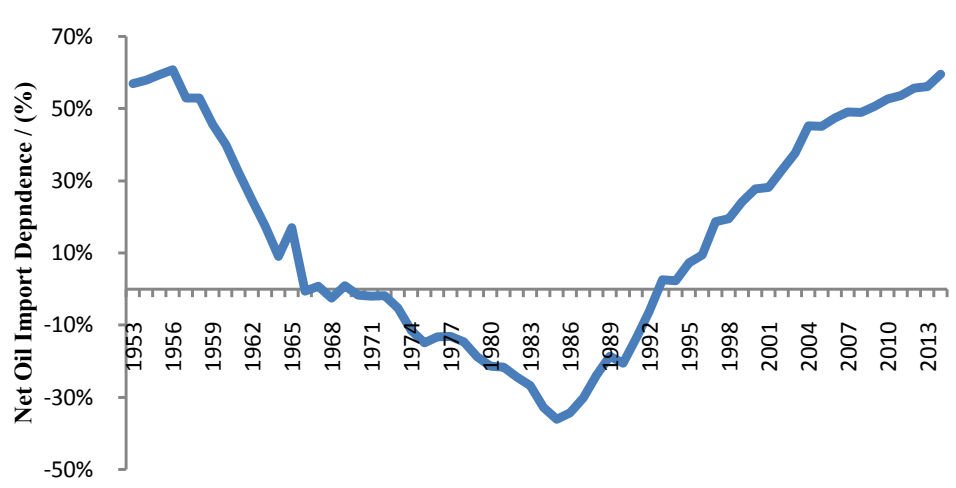

Figure 2. China's oil import dependence. Data source: Chinese statistical yearbook.

to 56 in 2014. However, in the same period, the $R / P$ of Middle East fell down from 120 to $90 ; R / P$ of America increased from 27 to $40 ; R / P$ of Africa increased from 30 to 44; $R / P$ of Europe and Eurasia increased from 17 to 23 ; $\mathrm{R} / \mathrm{P}$ of Asia-Pacific region declined from 18 to 16 [15]. $R / P$ of China has decreased from 19.6 in 1985 to 11.2 in 2008. Since 2009, $R / P$ has experienced a slight growth up to 11.9 in 2014, which was higher than Indonesia (11.6), Turkmenistan (7.1), Denmark (10.3), the United Kingdom (9.5) and Mexico (10.6) in comparison with the world's major oil producing countries. China's $R / P$ is on the edge of the unsafety line of 12 , and with a slight growth since the year of 2008, that might be partly attributed to the high crude oil price in this period, which promoted exploration and reserve discovered.

2) Risk Adjusted Diversify Index of Oil Imports

$R D I$ is used to indicate the supply concentration of oil imports from resource countries. The more the oil importing sources and the more balanced structure of oil imports, the lower the risk comes from supply disruptions. Based on the research from Cohen (2011) [7] and Zhang et al. (2013) [10], a country-specific diversification index adjusted by political risk (data from International Country Risk Guide, ICRG) was proposed.

$$
\begin{aligned}
& R D I=\sum_{i}\left[\left(\frac{N O I_{i}}{T O I}\right)^{2} \times C P R_{i} \times 100\right] \\
& N O I_{i}=\operatorname{Max}\left\{0, M_{i}-X_{i}\right\} \\
& C P R_{i}=\left(100-P O L_{i}\right) / 100
\end{aligned}
$$

where, $R D I$ is defined as country-specific diversification index adjusted by political risks, and the smaller the $R D I$ value, the more diversified of oil imports; $N_{i}$ is defined as net oil imports from country $i$; TOI is defined as total oil imports; $C P R_{i}$ is the country-specific political risk, with its value in range of 0 - 100; $P O L_{i}$ is political risk score for country $i$ from ICRG; $M_{i}$ is defined as oil imports from country $i ; X_{i}$ is defined as oil export from country $i$. 
The oil imports composition of China from 1990 to 2015 is shown in Figure 3, Figure 4. In 1995, the oil import from high risk countries (CPR greater than 0.3 ) accounted for $53.09 \%$ of total oil imports, however, the proportion reduced to $34.75 \%$ in $2000,28.68 \%$ in $2005,29.77 \%$ in 2010 and $30.63 \%$ in 2015 . In 1995 , the oil imports from low risk countries ( $C P R$ less than 0.2) accounted for $25.15 \%$, and the proportion was $33.95 \%$ in $2000,29.63 \%$ in $2005,37.39 \%$ in 2010 , and $32.75 \%$ in 2015. In regard to importers' country risk, China's are optimizing the oil sources countries by importing about $30 \%, 40 \%$ and $30 \%$ from low risk, medium risk and high risk countries respectively. In 1995, China's oil imports from the top ten oil source countries accounted for $75.24 \%$, the proportion was $80.29 \%$ in $2000,79.62 \%$ in $2005,92.19 \%$ in 2010 , and $83.28 \%$ in 2015 . The $R D I$ is calculated according to Equation (1) and shown in Figure 4 and Figure 5. During the past two decades, the $R D I$ has been on declining, which indicates China has been very concerned about its oil imports diversification and has achieved significant improvement on it.

\subsection{The Affordability of Oil Imports}

Two indicators of net oil imports cost to GDP ratio $(C / G P)$ and transportation distance index of oil imports ( $T D I)$ are used to assess the affordability dimension of China's oil security.

1) Net Oil imports Cost to GDP Ratio

$C / G P$ is defined as the cost of imported oil as a percentage of GDP, indicating the effects of oil imports cost on the national economy. $C / G P$ is determined by oil import volume times import price divided by GDP. The higher the indicator, the more China pays for importing crude oil, and the higher of the negative impact does the imported oil exert on the economy. China's $C / G P$ rose from $0.32 \%$ in 1995 to the peak point of $2.90 \%$ in 2012; turning points appeared in year 1998, 2009 and 2014, which were due to the sharply falling down of the oil price and the influences from Financial Crisis on China's oil consumption and importing. From 1999 to 2012, ClGP of China had a higher growth rate than that of U.S.

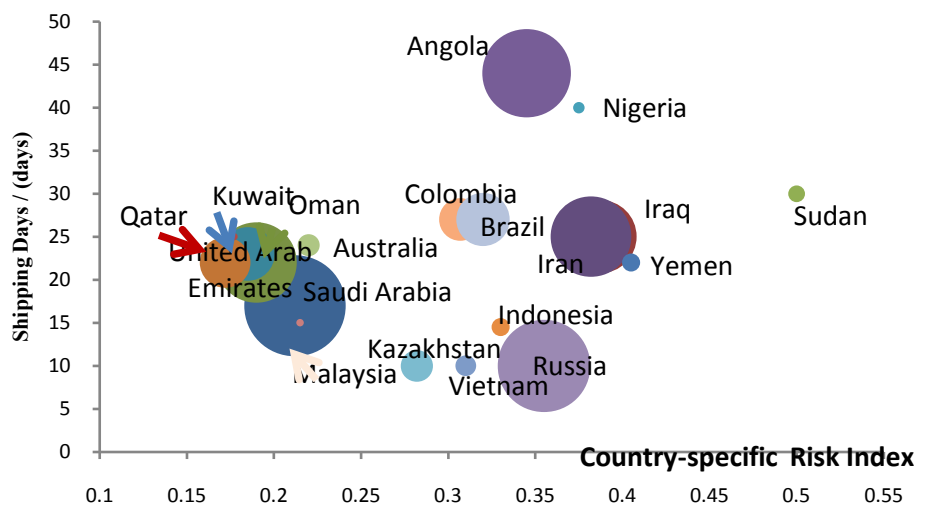

Figure 3. Country Risks, Shipping Days and Oil Imports from Oil Source Countries in 2015. Data Source: Chinese Customs. Notes: The area of the bubble denotes the country's oil exports volume to China. 
Oil Imports Composition in 1995

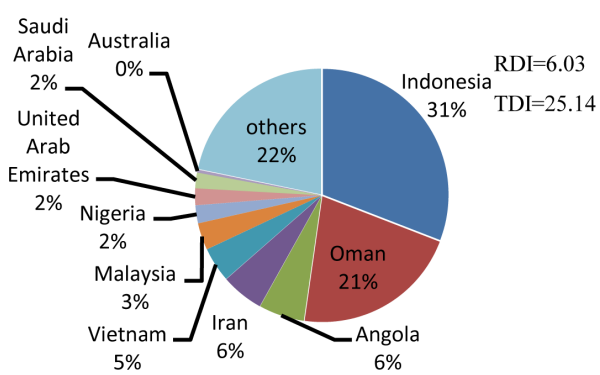

Oil Imports Composition in 2005

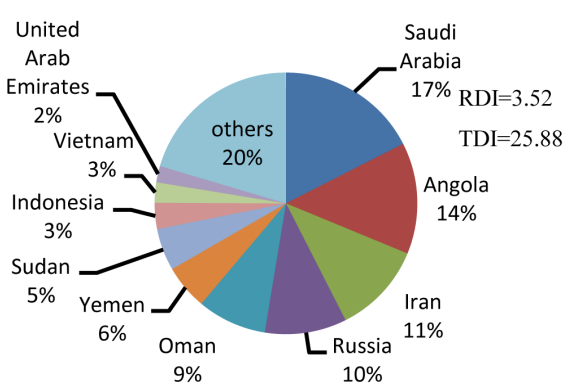

Oil Imports Composition in 2000
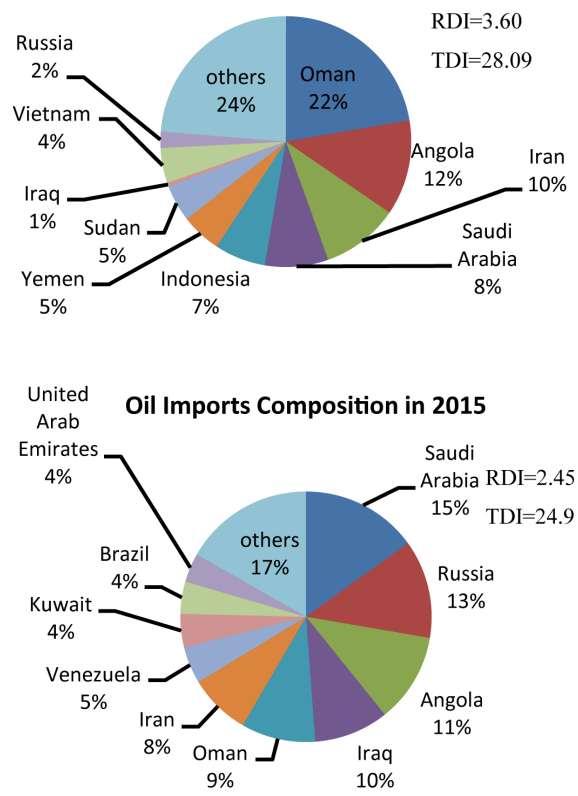

Figure 4. China's Top 10 oil resource countries, and Annual RDI and TDI. Data source: Chinese customs.

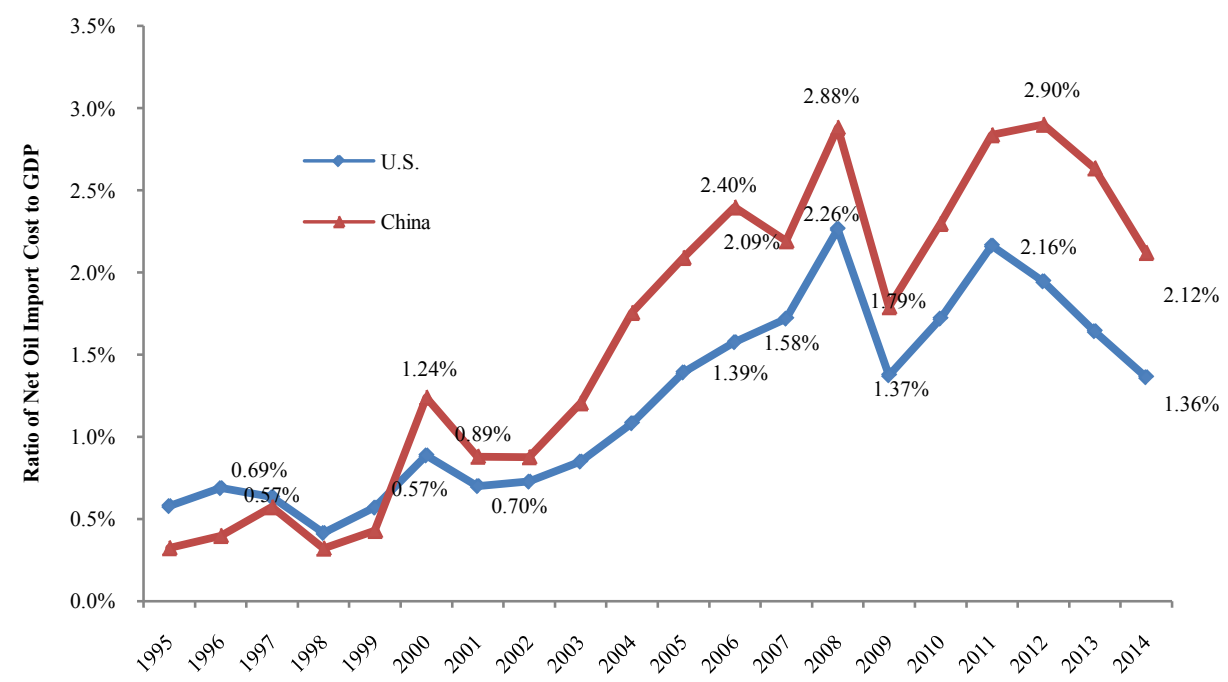

Figure 5. Ratio of oil imports cost to GDP. Data source: EIA, Chinese statistical yearbook, and Chinese energy statistical yearbook.

and since 2012, $C / G P$ of China has declined more sharply than that of U.S., indicating China's $C / G P$ was more sensitive to oil price (see Figure 5).

2) Transportation Distance Index of Oil Imports

Transportation distance index of oil imports as shown in Equation (4) is proposed and used in this paper to assess the transportation cost of oil imports. There are three main ways of shipping, railroad and pipeline in oil transportation, among which shipping is relatively cheaper and more convenient, ac- 
counting for over $60 \%$ of the total global oil transportation. Transportation cost is another issue of oil imports affordability, which is closely related to shipping distance. In this study, transportation distance index is defined based on importing oil sources and shipping voyage.

$$
T D I=\sum_{i} N O I_{i} \times D_{i} \times 10
$$

where, $D_{i}$ is defined as shipping voyage (SV). If SV from the source country to China is less than or equals 10 days, $D_{i}=1$; if SV is in the range of $11-20$ days, $D_{i}=2$; if SV is in the range of $21-30$ days, $D_{i}=3$; if SV is in the range of $31-40$ days, $D_{i}=4$; if SV is in the range of $41-50$ days, $D_{i}=4$. According to Lu (2014) [11] the construction of pipeline has a positive role in improving the security of crude oil supply. As Russia and Kazakhstan both have oil pipelines directly connected with China, their SV is assumed to be $D_{i}=1$.

$T D I$ (see Figure 6) had a sharp rise in 2000 which might be the result of China's oil importing diversification, as China imported more crude oil from Middle East and Africa since that year. However, in the following 15 years, TDI did not increase further (except the year 2010), which was the result of the balancing of oil importing from far sources in South America and near sources in the former Soviet Union region. In this sense, our research doesn't fully support what Reference [16] claimed that current Chinese policies gave much concerns on "reliable and adequate supply of oil" and pay relatively less attention to the maintenance of "reasonable price".

\subsection{The Efficiency of Oil Usage}

The GDP per capita oil consumption $(O / G P)$ is used to assess oil consumption intensity and efficiency of China. The lower the $O / G P$, the higher efficient of the oil consumption, and the more secured of the oil supply. O/GP China has declined from 2.49 ton/104 yuan in 1978 to 0.08 ton/104 yuan in 2014 [17]. The $O / G P$ of the major energy consuming countries are calculated and classified in

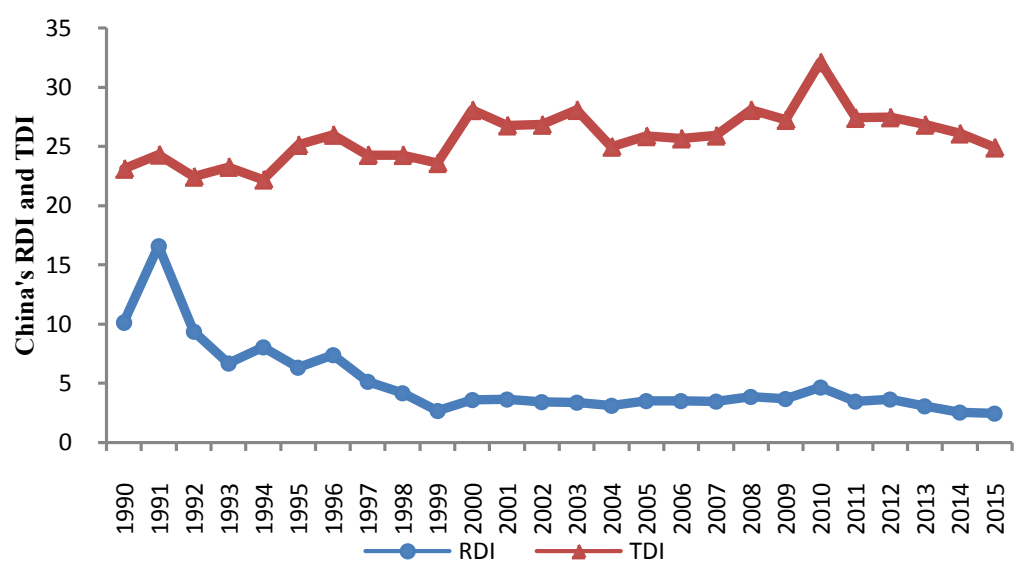

Figure 6. China's risk adjusted diversify index and transportation cost index of oil imports. Data source: Chinese customs. 
this paper (see Figure 7). South Korea, India, Mexico and China belonged to the higher oil intensity countries; U.S., Canada and Brazil had medium $O / G P$; Japan and other European countries had lower $O / G P$. However, China has the most rapid oil intensity decrease rate of $4.46 \%$ in the past 15 years, and in 2014 its oil intensity was very close to that of Canada and Brazil.

\section{Overseas Mergers and Acquisitions from Chinese NOCs}

According to our summaries of published reports, from the early 1990s, led by the three major Chinese National Oil Companies (NOCs) of CNPC ${ }^{1}$, Sinopec ${ }^{2}$ and $\mathrm{CNOOC}^{3}$, Chinese companies have invested in more than 150 overseas mergers and acquisitions (M\&As) with a cumulative cost of more than $\$ 160$ billion. Among them, during period of 1993-2006, 77 M\&A deals closed at atal contract price of $\$ 20$ billion; during period of 2007-2013, 84 M\&A deals closed at price of $\$ 142$ billion; and CNPC, Sinopec, CNOOC accounted for $41.3 \%$, $18.3 \%$ and $30 \%$ of the total contract price, respectively. The M\&As for the oil and natural gas reserves accounted for $75 \%$ and $15 \%$ respectively, and the others were for refineries and LNG terminals. The overseas M\&As from Chinese oil and gas companies have slowed down since 2014.

Among the total investment, equity trading accounted for more than 50\%, and acquisition of companies accounted for about $45 \%$. North America accounted for $33 \%$ of the total contract price, South America, Mid-Asia (including Russia), Africa, Asian-Pacific and Europe accounted for 18\%, 16\%, 15\%, 11\% and 7\%, respectively. The percentage of investment on conventional and unconventional onshore resource was $26 \%$ and $24 \%$; on offshore resources was $30 \%$; and others are on a variety of assets. Notably, investment on production projects accounted for $63 \%$, on in-building projects accounted for $31 \%$, on risk exploration

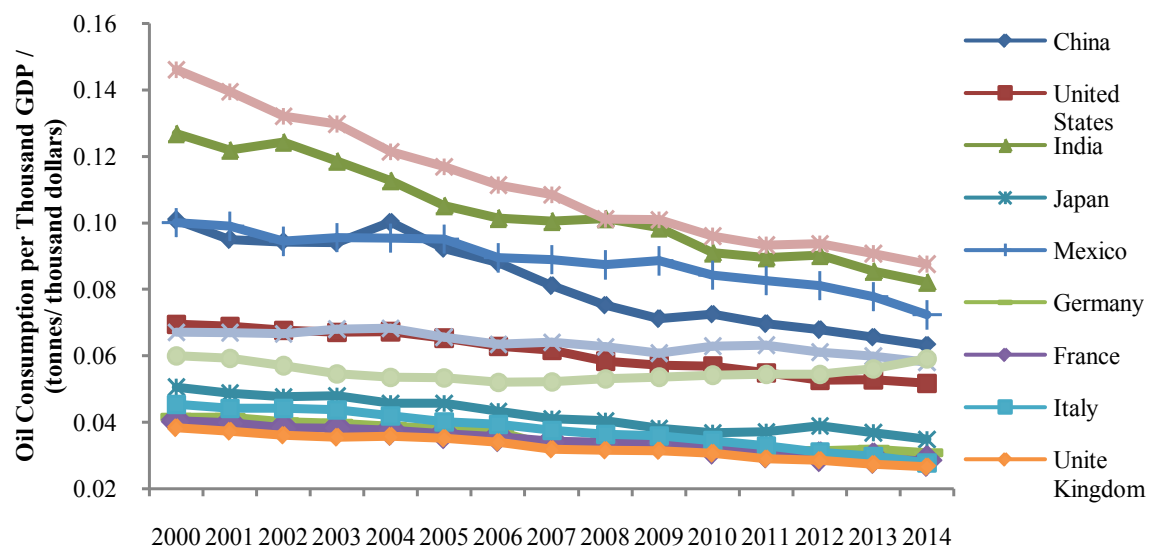

Figure 7. Oil intensity from major oil consuming countries. Data source: GDP from the world bank, GDP at market prices (constant 2010 US\$); Oil consumption from BP statistical review, 2016.

${ }^{1}$ China National Petroleum Corporation (CNPC).

${ }^{2}$ China Petroleum \& Chemical Corporation (Sinopec).

${ }^{3}$ China National Offshore Oil Corporation (CNOOC). 
projects accounted for only 5\%. In all, Chinese oil and gas companies' overseas investment focused on relatively matured oil and gas projects, and has shifted to North and South America market, unconventional and offshore resources, and natural gas resource.

As China's NOCs continuously expanding the overseas investment in the past two decades, overseas equity oil production (OEOP) kept rising. In 2015, according to annual reports from Chinese NOCs, CNPC's OEOP was $55 \mathrm{Mt}$, those of Sinopec and CNOOC were $7 \mathrm{Mt}$ and 32Mt. However, according to data from Wood Mackenzie, OEOP from the three major NOCs was about $88 \mathrm{Mt}$ in 2015. The estimated total OEOP from CNPC, Sinopec and CNOOC are shown in Figure 8, which indicates that OEOP will increase in the next 12 years to $110.84 \mathrm{Mt}$ in 2028, and then decline if there were no follow-up projects. Since 2035, with the expiration of contracts in Iraq, Brazil and Canada, there will be a "cliffdown" decline in total overseas OEOP.

In addition, according to China's current OEOP composition, OEOP from Iraq accounts for $20.4 \%$, Kazakhstan accounts for $15.2 \%$, Nigeria $9.1 \%$, Sudan $4.9 \%$, and Canada 6.6\%. In the peak production year of 2028, the OEOP from Iraq is expected to account for $42.6 \%$, Brazil $13.0 \%$, Canada $12.1 \%$, Kazakhstan $5.8 \%$ and Venezuela $4.9 \%$. In the next decade, Iraq, Canada, Kazakhstan, Venezuela will become the key source countries of OEOP, while OEOP from Nigeria, Sudan and other countries will decrease if without further investments.

In 2015, the total oil imports of China was about $335 \mathrm{Mt}$, of which 50\% from Middle East, 14\% from Russia and Kazakhstan, 12\% from Africa and 12\% from South America. In the same year, the OEOP from China's three major NOCs was about $90 \mathrm{Mt}$, in which 27\% from Middle East, 26\% from Africa, 14\% from Russia and the former Soviet Union countries, 11\% from South America and 9\% from North America. The OEOP was more diversified than the oil imports. It was reported that only $1 / 8-1 / 10$ of the overseas OEOP was shipped back to China due to the NOCs' profits expectation and optimization and the high shipping cost. However, the investment on overseas oil and gas market has multi-

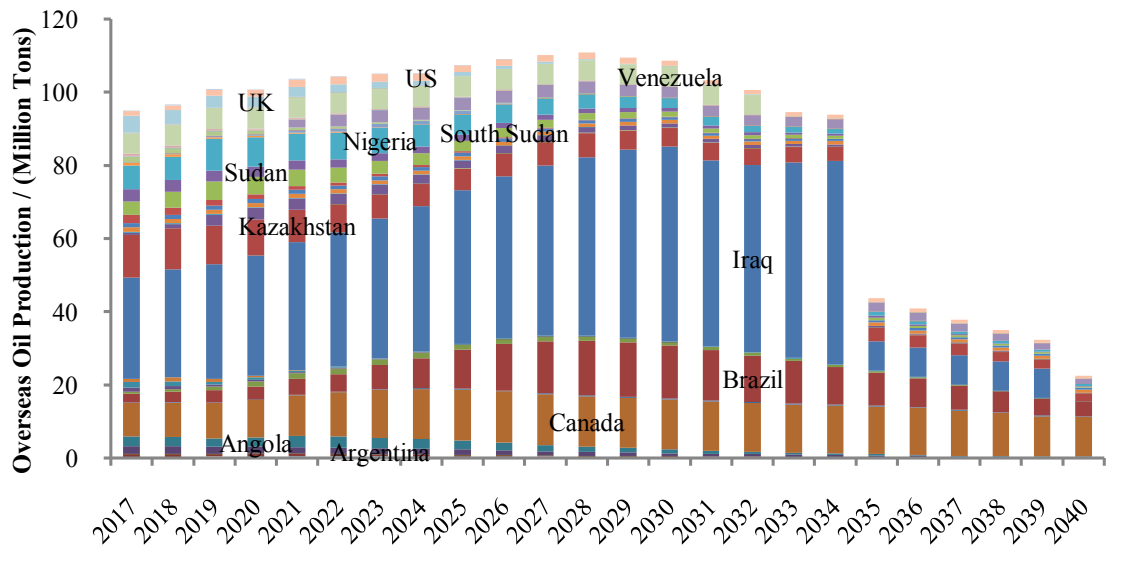

Figure 8. Estimated overseas oil production from the three major NOCs. Data source: Wood Mackenzie. 
purposes besides that. First, the overseas M\&As were encouraged and supported by Chinese government as part of the so called going out policies to diversify foreign exchange reserves to resource reserves for a higher rate of return and a more balanced portfolio (Zhang 2012 [18], Tan 2013 [19]). Second, the overseas M\&As were usually followed by exporting of project constructions, oilfield services and complete sets of equipment. According to CNPC, the contract price of oil field services and equipment exporting almost equaled to its overseas investment on oil and gas resources. Third, the M\&As on overseas companies were expected to enhance Chinese NOCs' technological and managerial experiences. Fourth, the overseas investment and its yields of OEOP gave Chinese NOCs the opportunity to evaluate which was more economical between shipping equity oil back and buying crude oil in the neighboring regions. Therefore, Chinese NOCs would be more comparative and influential in regional oil resource market. However, the contracted OEOP from the three major NOCs averages about $100 \mathrm{Mt}$ annually during 2016 2030, if needed for the emergency of oil supply disruptions; it would play a back-up role in China's oil supply.

\section{Conclusions and Suggestions}

Both Chinese government and NOCs concern seriously about the domestic oil exploration and development, and due to declining of conventional oil production, they are actively engaging in developing of unconventional resources. On the other hand, China is using diversification of oil sources as the primary means to reduce oil importing risks, resulting in RDI on a continuous decrease and TDI relatively stable in the past two decades. New sources of crude oil from the world market were discovered and added into the import mixes and oil import transportation was improved. China relied heavily on oil imports from South East Asia and Middle East in the early 1990's and increased the proportion of oil imports from Africa since the new millennium, due to its surplus of oil supply and light sweet of oil quality. In recent years, oil imports from both the former Soviet Union countries and from South America increased dramatically. The reason for the enhanced oil imports from former Soviet Union countries can be attributed to the commercially operating of China-Kazakhstan and China-Russia pipelines, which were looked as high efficient and low risk way of oil transportation. In terms of oil source countries' political risks, the ratio of China's oil imports from high, medium and low risk countries is 30:40:30 now, which is much better than 53:22:25 twenty years ago.

The Chinese NOCs have invested worldwide intensively during the past two decades with the focus being transferred from Asia-Pacific and Africa to Middle East and Russia (and the former Soviet Union countries). The M\&As for unconventional oil and gas in the investment portfolio have risen in recent years. Most of the overseas M\&As were on mature production assets. Overseas equity oil production from Iraq accounts for $20 \%-40 \%$ of the total OEOP. Kazakhstan, Canada and Brazil are also major sources of OEOP in current assets portfolios. 
Future OEOP will rely heavily on high risk regions (Iraq), deep water assets (Brazil) and unconventional resources (Canada oil sands). Thus the economics of OEOP will depend on oil price, technical improvement and stability of international politics. In 2015, China's crude oil imports were $335 \mathrm{Mt}$ in total and the OEOP was about $120 \mathrm{Mt}$. In this sense, although only a small part of the OEOP was shipped back to China in the past, it may undertake many functions including a backup for national oil supply and oil security.

Enhancing oil security is the key issue for China's sustainable development and it requires further efforts from both supply side and demand side. The demand side oil security policies should focus on demand growth control. In China, transportation oil consumption has surpassed industrial oil consumption in 2010, and in 2014, oil consumptions in transportation and household (mainly private cars use) sectors accounted for $48 \%$ of total oil consumption. According to our estimation, by 2030, the transportation consumption of oil products including gasoline, diesel and kerosene will account for $68 \%$ of total oil products consumption. Therefore, the decreasing of oil intensity and increasing of oil use efficiency should focus on transportation sector by improving engine efficiency, promoting electric vehicle techniques and optimizing city transportation systems.

On the other hand, policies to improve oil supply security include: 1) Improving domestic oil production, especially from remaining oil, offshore and unconventional reserves, which rely heavily on high efficiency, green development technologies. Through cooperation and self-innovation, technological improvement would be the hope in maintaining and increasing domestic oil supply; 2) Securing diversity of oil imports mixes and lowering importing risks. According to EIA [20], during period of 2010-2015, the domestic crude production from U.S. increased by 3.2 million b/d, and crude imports fell by 1.9 million $\mathrm{b} / \mathrm{d}$, due to the increased oil production from shale oil. Furthermore, US Congress lifted the 40-year ban on exporting crude oil, which is expected to trigger its domestic oil production. The oil importing reduction from the largest oil consuming country might provide a more favorable environment for China to make good deals in importing and further optimize imports sources; 3) Securing oil transportation safety. China's transnational pipelines consist of the NorthEast pipeline (Russia-China) with maximum capacity of $30 \mathrm{Mt}$, North-West pipeline (Kazakhstan-China) with maximum capacity of $50 \mathrm{Mt}$, and South-West pipeline (Burma-China) and with maximum capacity of $30 \mathrm{Mt}$. Therefore, about $3 / 4-4 / 5$ of oil imports will still count on shipping. In 2014, China's oil imports by its own tanker fleet accounted for only $40 \%$, which was much lower than the originally planned proportion of $80 \%$ in 2015 . From the oil security point of view, increasing China's own shipping fleet number and volume is imminent to oil transportation safety.

In this paper, an indicator system was proposed for evaluating oil security in China and China's policies regarding this issue were discussed. Limitation in this 
research is the missing of an integrated method to comprehensively assess various dimensions of oil security. Future efforts are need to explore the interaction of different dimensions and develop new method to fully describe the complexity of oil security issue. Furthermore, new trends in China's overseas oil investment when facing low oil price, are also needed to be identified and studied.

\section{Acknowledgements}

Funding for this work was supported by China's National Social Science Fund (No. 11\&ZD164 and No. 13\&ZD159) and by Scientific Research Foundation of China University of Petroleum, Beijing (No. 2462015YQ0716).

\section{References}

[1] Zou, G. and Chau, K.W. (2006) Short- and Long-Run Effects between Oil Consumption and Economic Growth in China. Energy Policy, 34, 3644-3655. https://doi.org/10.1016/j.enpol.2005.08.009

[2] Zheng, Y. and Luo, D. (2013) Industrial Structure and Oil Consumption Growth Path of China: Empirical Evidence. Energy, 57, 336-343. https://doi.org/10.1016/j.energy.2013.05.004

[3] Costantini, V., Gracceva, F., Markandya, A. and Vicini, G. (2007) Security of Energy Supply: Comparing Scenarios from a European Perspective. Energy Policy, 35, 210 226. https://doi.org/10.1016/j.enpol.2005.11.002

[4] Jun, E., Kim, W. and Chang, S.H. (2009) The Analysis of Security Cost for Different Energy Sources. Applied Energy, 86, 1894-1901. https://doi.org/10.1016/j.apenergy.2008.11.028

[5] Vivoda, V. (2009) Diversification of Oil Import Sources and Energy Security: A Key Strategy or an Elusive Objective? Energy Policy, 37, 4615-4623.

https://doi.org/10.1016/j.enpol.2009.06.007

[6] Vivoda, V. (2010) Evaluating Energy Security in the Asia-Pacific Region: A Novel Methodological Approach. Energy Policy, 38, 5258-5263. https://doi.org/10.1016/j.enpol.2010.05.028

[7] Cohen, G., Joutz, F. and Loungani, P. (2011) Measuring Energy Security: Trends in the Diversification of Oil and Natural Gas Supplies. Energy Policy, 39, 4860-4869. https://doi.org/10.1016/j.enpol.2011.06.034

[8] Wu, G., Wei, Y.M., Fan, Y. and Liu, L.C. (2007) An Empirical Analysis of the Risk of Crude Oil Imports in China Using Improved Portfolio Approach. Energy Policy, 35, 4190-4199. https://doi.org/10.1016/j.enpol.2007.02.009

[9] Wu, G., Liu, L.C. and Wei, Y.M. (2009) Comparison of China's Oil Import Risk: Results Based on Portfolio Theory and a Diversification Index Approach. Energy Policy, 37, 3557-3565. https://doi.org/10.1016/j.enpol.2009.04.031

[10] Zhang, H.Y., Ji, Q. and Fan, Y. (2013) An Evaluation Framework for Oil Import Security Based on the Supply Chain with a Case Study Focused on China. Energy Economics, 38, 87-95. https://doi.org/10.1016/j.eneco.2013.03.014

[11] Lu, W., Su, M., Zhang, Y., Yang, Z., Chen, B. and Liu, G. (2014) Assessment of Energy Security in China Based on Ecological Network Analysis: A Perspective from the Security of Crude Oil Supply. Energy Policy, 74, 406-413. https://doi.org/10.1016/j.enpol.2014.08.037

[12] Gupta, E. (2008) Oil Vulnerability Index of Oil-Importing Countries. Energy Policy, 
36, 1195-1211. https://doi.org/10.1016/j.enpol.2007.11.011

[13] Ediger, V.Ş. and Berk, I. (2011) Crude Oil Import Policy of Turkey: Historical Analysis of Determinants and Implications since 1968. Energy Policy, 39, 2132 2142. https://doi.org/10.1016/j.enpol.2011.01.058

[14] Greene, D.L. (2010) Measuring Energy Security: Can the United States Achieve Oil Independence? Energy Policy, 38, 1614-1621. https://doi.org/10.1016/j.enpol.2009.01.041

[15] British Petroleum (2016) BP Statistical Review of World Energy. British Petroleum, London.

[16] Li, R. and Leung, G.C.K. (2011) The Integration of China into the World Crude Oil Market since 1998. Energy Policy, 39, 5159-5166. https://doi.org/10.1016/j.enpol.2011.05.048

[17] National Bureau of Statistics of China (2016) China Statistical Yearbook. National Bureau of Statistics of China, Beijing.

[18] Zhang, Z. (2012) The Overseas Acquisitions and Equity Oil Shares of Chinese National Oil Companies: A Threat to the West but a Boost to China's Energy Security? Energy Policy, 48, 698-701. https://doi.org/10.1016/j.enpol.2012.05.077

[19] Tan, X. (2013) China's Overseas Investment in the Energy/Resources Sector: Its Scale, Drivers, Challenges and Implications. Energy Economics, 36, 750-758. https://doi.org/10.1016/j.eneco.2012.11.019

[20] Energy Information Administration (2015) Effects of Removing Restrictions on U.S. Crude Oil Exports. Energy Information Administration, Washington DC.

\section{Submit or recommend next manuscript to SCIRP and we will provide best service for you:}

Accepting pre-submission inquiries through Email, Facebook, LinkedIn, Twitter, etc. A wide selection of journals (inclusive of 9 subjects, more than 200 journals)

Providing 24-hour high-quality service

User-friendly online submission system

Fair and swift peer-review system

Efficient typesetting and proofreading procedure

Display of the result of downloads and visits, as well as the number of cited articles

Maximum dissemination of your research work

Submit your manuscript at: http://papersubmission.scirp.org/

Or contact ajibm@scirp.org 